\title{
PENGARUH APLIKASI VIRGIN COCONUT OIL TERHADAP PENINGKATAN JUMLAH FIBROBLAS PADA LUKA PASCA PENCABUTAN GIGI PADA RATTUS NOVERGICUS
}

\author{
Anggun Hibah Jannah Tamara*, Yayun Siti Rochmah ${ }^{* *}$, Rochman Mujayanto ${ }^{* *}$
}

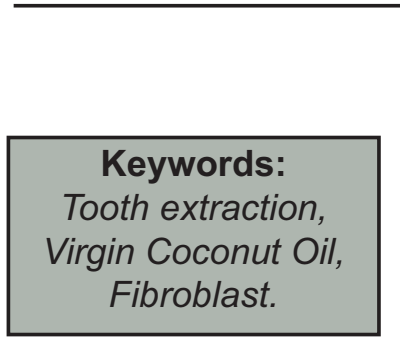

\section{ABSTRACT}

Background: Wound healing is a complex biological process. Fibroblast is one of cell which is responsible for the wound healing process. Virgin Coconut Oil (VCO) have health benefit as antibacterial, antiinflamatory, antioxidant, and immunomodulatory. This research was purposed to know the influence use of VCO over the amount of fibroblast in wound healing after dental extraction.Method: Research quasi experimental with post test control group design and using 15 Rattus novergicus which were divided into three groups (control positive, VCO topical application, and VCO per oral application). Tooth removal was committed by using explorer, scalpel-blade, and arterial clamp. Then VCO applied everyday for 7 days. Day 7 th Rattus novergicus were died, the socket after extraction were made into histological form, then the amount of fibroblast were counted with 5 field of views and made in average. Result: The number of fibroblast of the most numerous was VCO per oral ( 48,6 $\pm 49,8)$, VCO topical ( $36,2 \pm 38,8$ ), and control positive ( $33,4 \pm 35,2)$. The results of the Saphiro Wilk test and Levene test acquired data normally distributed and homogeny, so it continued to One Way Anova and data showed there were significant difference among the groups of samples with value $p<0,05$.Conclusion: The conclusion of this research is VCO could increase the number of fibroblasts in wound healing after dental extractions

\section{PENDAHULUAN}

Pencabutan gigi merupakan terapi masalah gigi yang dilakukan oleh dokter gigi. Pencabutan gigi adalah pengambilan gigi atau akar gigi tanpa rasa nyeri namun dengan perlukaan minimal pada jaringan dan tulang pendukung yang mengelilinginya ${ }^{1}$.

Pencabutan gigi berhasil jika disertai proses penyembuhan sempurna. Ketika hal tersebut tidak tercapai, maka menimbulkan masalah yang tidak kalah rumit, bahkan mempengaruhi keadaan sistemik pasien. Untuk itu, proses penyembuhan luka merupakan hal yang perlu diperhatikan oleh dokter gigi karena efeknya menimbulkan nyeri dan rasa ketidaknyamanan dalam rongga mulut ${ }^{2}$.
Gigi yang dicabut menyisakan soket terdiri dari korteks tulang, terlindungi oleh ligamen periodontal dengan gingiva sebagai lapisan paling luar. Soket akan terisi oleh darah, nantinya berkoagulasi membentuk blood clotdan menutup seluruh soket dari lingkungan rongga mulut. Luka pasca pencabutan secara normal akan mengalami penyembuhan dengan sendirinya, membutuhkan waktu 3-4 minggu hingga stage inflamasi sampai fibroplasi berakhir ${ }^{3}$.

Tanaman kelapa banyakdi Indonesia, dilihat dari luasnya perkebunan kelapa mencapai jutaan hektar. Produksi kelapa di Indonesia menempati urutan kedua di dunia. Pemanfaatan buah kelapa banyak digunakan sebagai bahan makanan. 
Saat ini pemanfaatan buah kelapa telah berkembang dalam bidang kesehatan salah satunya adalah dengan pembuatan Virgin Coconut Oil (VCO) ${ }^{4}$.

Virgin Coconut Oil merupakan minyak kelapa murni, dibuat dari daging kelapa segar, diolah dalam suhu rendah, sehingga kandungan penting dalam minyak tetap dapat dipertahankan ${ }^{5}$. Hingga saat ini VCO diketahui memiliki kemampuan melembabkan luka, mempercepat metabolisme sel, anti inflamasi dan anti infeksipada luka bakar kimiawi. Virgin Coconut Oil terbukti mempercepat waktu penyembuhan luka dan memiliki presentase kesembuhan paling tinggi terhadap luka bakar kimiawi pada Rattus novergicus ${ }^{6}$. Penelitian yang dilakukan pada 18 Sprague-Dawley dengan luka eksisi, membuktikan bahwa VCO mampu meningkatkan proliferasi sel fibroblast sehingga kepadatan serat kolagen meningkat ${ }^{7}$.

Penelitian ini bertujuan untuk mengetahui pengaruh aplikasi VCO terhadap jumlahfibroblas pada penyembuhan luka pasca pencabutan gigi.

\section{METODE PENELITIAN}

\section{Jenis penelitian}

yang digunakan kuasi

eksperimental, dengan rancangan Post Test Control Group Design. Subyek penelitian 15 ekor tikus jenis Rattus novergicus, dibagi menjadi 3 kelompok : kelompok kontrol positif (K1), kelompok perlakuan I (K2), dan kelompok perlakuan II (K3). K1 diberikan aplikasi Povidon iodine, K2 diaplikasi VCO topikal dengan sediaan berupa emulgel, dan K3 diaplikasi VCO per oral. Per kelompok terdiri dari 5 ekor tikus, dengan setiap ekornya mendapatkan aplikasi setiap hari sekali selama 7 hari. Kemudian diobservasi dan dibandingkan pengaruh aplikasi VCO terhadap jumlah fibroblas yang terbentuk.

Sampel dalam penelitian ini adalah tikus jenis Rattus novergicus yang dipelihara di Laboraturium Fakultas MIPA Universitas Negeri Semarang dengan usia 2,5-3 bulan dan berat badan 150200 gram.Penelitian dillaksanakan di Laboraturium Biologi Universitas Negeri Semarang, Klinik dan Pet Shop Griya Satwa Lestari, Laboratorium Akfar Theresiana, dan Laboratorium Patologi Anatomi Fakultas Kedokteran Universitas Islam Sultan Agung Semarang pada Oktober-November 2013.Pada penelitian ini VCO dibuat dengan sediaan emulgel untuk memudahkan aplikasi VCO ke dalam soket.

Tabel 1.Hasil rata-rata jumlah fibroblas pada masing-masing kelompok perlakuan dengan pengamatan 5 lapangan pandang

\begin{tabular}{lc}
\hline Kelompok & Rerata jumlah fibroblas \\
\hline & 34,4 \\
& 33,4 \\
Kl (Povidone iodine) & 35,2 \\
& 34,2 \\
& 34 \\
\hline & 36,2 \\
K2 (VCO Aplikasi topikal) & 37,6 \\
& 37,4 \\
& 38,8 \\
& 37,8 \\
\hline & 48,6 \\
K3 (VCO Aplikasi per oral) & 49 \\
& 49,4 \\
& 49,4 \\
\end{tabular}

Tikus dilakukan anestesi menggunakan ketamin dan xylazil i.m dosis $75 \mathrm{mg} / \mathrm{kgBB}$ dan $5 \mathrm{mg} / \mathrm{kgBB}$. Kemudian dilakukan pencabutan gigi tikus menggunakan arteri klem pada gigi incisivus sentral kanan mandibuladan diberi aplikasi VCO selama 7 hari. Untuk mencegah infeksi dan rasa nyeri, maka diberikan antibiotik dan analgesik10. Hari ke-7 tikus dimatikan dan mandibula tikus dipotong di mana terdapat soket gigi yang sudah dicabut untuk dibuat sediaan histokimia atau preparat. Preparat diamati di bawah 
mikroskop dengan perbesaran 400x dan 5 lapangan pandang ${ }^{8}$.

Analisa data dilakukan uji normalitas dan homogenitas menggunakan
$\mathrm{K} 2$

Uji normalitas dan homogenitas dilakukan pada ketiga kelompok dengan

Tabel 2. Uji One 4 Hasil Way Anova

\begin{tabular}{ccc}
\hline Fibroblas & $\begin{array}{c}\text { Probabilitas uji One Way } \\
\text { Anova }\end{array}$ & Keterangan \\
\hline $\begin{array}{c}\text { Antara dua kelompok } \\
\text { Dalam kelompok }\end{array}$ & 0,000 & Beda signifikan \\
\hline
\end{tabular}

Tabel 3. Hasil Uji Post Hoc

\begin{tabular}{lccc}
\hline Kelompok perlakuan & K1 (Povidone iodine) & K2 (VCO topikal) & K3 (VCO per oral) \\
\hline K1 (Povidone iodine) & 0,000 & 0,000 & 0,000 \\
K2 (VCO topikal)) & 0,000 & 0,000 & 0,000 \\
K3 (VCO per oral) & & & \\
\hline
\end{tabular}

Tabel 4. Hasil Uji Korelasi Pearson

\begin{tabular}{llc}
\hline & & Korelasi Pearson \\
\hline Povidone iodine & Fibroblas & 0,947 \\
Virgin Coconut Oil & Fibroblas & 0,947 \\
Fibroblas & Povidone iodine & 0,947 \\
Fibroblas & Virgin Coconut Oil & 0,947 \\
\hline
\end{tabular}

ujiSaphiro Wilk dan Levene test. Apabila data terdistribusi normal dan homogen selanjutnya dilakukan analisa data dengan uji One Way Anova, kemudian uji Post Hoc laluuji Korelasi Pearson. Derajat kepercayaan diberikan sebesar $95 \%(\alpha=$ $0,05)$.

\section{HASIL PENELITIAN}

Hasil penghitungan sel fibroblas Rattus novergicus $\mathrm{K} 1$, $\mathrm{K} 2$, dan $\mathrm{K} 3$ sebagai berikut

Pengamatan preparat soket bekas pencabutan Rattus novergicus menunjukkan kenaikan fibroblas seperti tercantum pada Tabel 1. K2 mengalami kenaikan fibroblas tidak begitu banyak dibandingkan dengan $\mathrm{K} 1$, sedangkan K3mengalami kenaikan jumlah fibroblas yang cukup banyak dibandingkan $\mathrm{K} 1$ dan hasil normal dan homogen, analisis dilanjutkan dengan uji One Way Anova (Tabel 2).

Setelah dilakukan uji beda, selanjutnya dilakukan uji Post Hoc (Tabel 3).

Uji korelasi Pearson. Nilai $p$ VCO dan fibroblas $=0,08-1$, yakni 0,947, terdapat korelasi sangat kuat antara VCO dengan peningkatan jumlah fibroblas (Tabel 4).

\section{DISKUSI}

Hasil penelitian K1 dan K2 jumlah fibroblas sedikit mengalami peningkatan karena K2 menggunakan VCO, dan berbeda secara signifikan, seperti yang ditunjukkan pada Tabel 1 dan Tabel 2. Virgin Coconut Oil mengandung Medium Chain Triglyceride (MCT)berupa asam laurat, flavonoid, dan tocopherol bersifat 
anti-inflamatory, anti-bacterial, dan antioxidant6. Maka luka pencabutan gigi, asam laurat, flavonoid, dan tocopherol berperan dalam pencegahan infeksi dan kerusakan sel yang berlebihan?. Tocotrienol berkemampuan sebagai histamine blocker yang mengurangi produksi kolagen, sehingga jaringan mempertahankan adhesivitas dan memproteksi jaringan yang terluka ${ }^{14}$. Ini berlawanan dengan sediaan povidon iodine berupa liquid, penetrasi kurang baik dan cepat hilang bila diaplikasikan topikal ${ }^{15}$.

Pada Tabel 1 juga menunjukkan hasil penelitian $\mathrm{K} 1$ dan $\mathrm{K} 3$ memiliki selisih
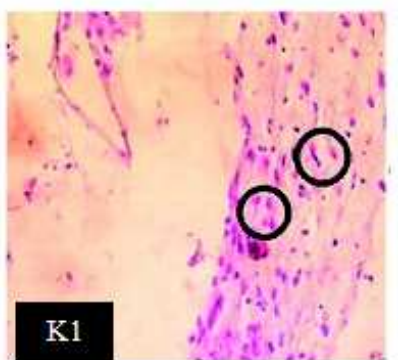

Keterangan :

K1 : Kel. Kontrol positif

K2 : Kel. Perlakuan I (VCO aplikasi topikal)

K3 : Kel. Perlakuan II (VCO aplikasi per oral
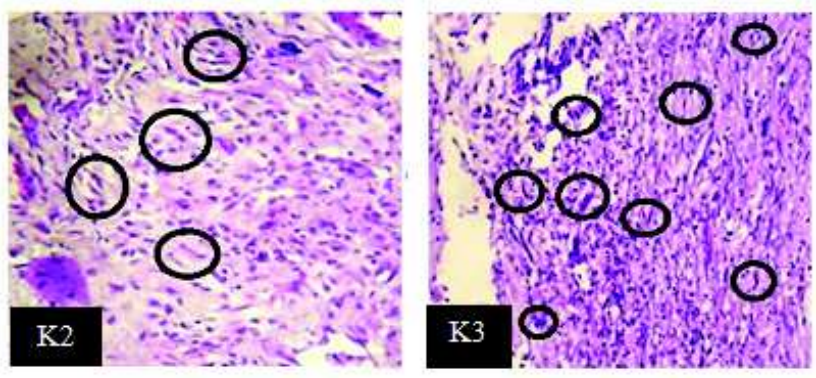

Gambar 1.Potongan membujur soket gigi Rattusnovergicus dengan pengecatan HE dan pembesaran $400 \mathrm{X}$ dengan menggunakan mikroskop digital. Lingkaran hitam menunjukkan sel fibroblas.

pasca injuri tidak terbentuk jaringan parut. Dengan keuntungan tersebut tocotrienol berfungsi sebagai anti-inflamatory pada penyembuhan luka, sehingga fase inflamasi dapat dilalui lebih cepat $^{10}$. Pendeknya fase inflamasi, akan semakin cepat menuju fase berikutnya, yaitu fase fibroplasi ${ }^{11}$.

Perbedaan bermakna pada Tabel 3 menunjukkan bahwa K2 sesuai teori yang dikemukakan Badman, yaitu asam laurat menstimulasi sel fibroblas oleh fibronektin ${ }^{12}$. Asam laurat berkaitan dengan aktivasi TGF- $\beta$. TGF- $\beta$ merupakan growth factor yang berproliferasi, kemudian menstimulasi fibronektin dalam pembentukan gumpalan benang fibrin ${ }^{9}$.Gumpalan benang fibrin yang terbentuk menjadi kerangka reepitelialisasi dan proliferasi fibroblas. Jadi apabila gumpalan fibrin cepat terbentuk, fibroblas segera berproliferasi sehingga secara otomatis fibroblas meningkat ${ }^{13}$. Sediaan diaplikasikan pada K2 ialah semisolid. Sediaan semisolid mampu fibroblas yang amat jauh, karena VCO mengandung substansi yang disebutkan di atas, sehingga mempengaruhi jumlah fibroblas. Tabel 3 juga menunjukkan perbedaan bermakna antara K1 dan K3. Aplikasi per oral yang dilakukan di K3 memaksimalkan kinerja MCT. Medium Chain Triglyceride ketika dalam tubuh akan diubah menjadi monolaurin ${ }^{16}$. Monolaurin bisa disintesis jika bereaksi dengan katalis, seperti enzim lipase ${ }^{17}$. Enzim lipase ada pada traktus gastrointestinal yang dimulai dari rongga mulut tepatnya saliva, hingga usus halus ${ }^{18}$. Dengan demikian, berbeda dengan $\mathrm{K} 1$ yang diberi povidon iodine yang diaplikasikan topikal.

Jumlah fibroblas K2 dan K3 menunjukkan selisih yang cukup jauh serta hasil yang signifikan, seperti yang ditunjukkan pada Tabel 1 dan Tabel 2. Ini dikarenakan K3 menggunakan sediaan VCO liquid, sehingga dosis dapat lebih akurat, yakni konsentrasi VCO ialah 100\%. Sedangkan K2 sediaan yang digunakan semisolid dan hanya mengandung VCO 
sebanyak 40\%, 60\% sisanya berupa emulgator, sehingga kurang efektif dalam proliferasi fibroblas. Pemberian obat per oral merupakan cara paling umum, namun membutuhkan waktu lebih lama karena melalui saluran pencernaan yang melewati banyak tempat, sehingga mempengaruhi bioavabilitas obat. Cara ini juga dikhawatirkan tidak mencapai reseptor sasaran. Sementara obat secara topikal memberikan efek langsung pada sasaran dengan onset of action yang cepat, namun tanpa mempengaruhi keadaan sisemik ${ }^{19}$.

Pada penelitian ini meskipun K2 diaplikasikan per oral, memungkinkan dosis efektif VCO mencapai reseptor sasaran tetap lebih tinggi dibandingkan dengan aplikasi topikal. Ini berkaitan dengan teori bahwa efektivitas obat dipengaruhi oleh dosis, cara pemberian, sediaan, serta kerja obat itu sendiri, salah satunya waktu paruh. Waktu paruh ialah waktu yang dibutuhkan tubuh untuk mengeliminasi obat hingga terdapat dosis efektif yang tersisa dalam tubuh ${ }^{15}$. Sebelumnya disebutkan bahwa MCT ketika dalam tubuh diubah menjadi monolaurin $^{16}$. Monolaurin bisa disintesis jika bereaksi dengan katalis, seperti enzim lipase $^{17}$.

Pada aplikasi per oral, obat melalui proses pencernaan, dan enzim lipase ada pada traktus gastrointestinal yang dimulai dari rongga mulut tepatnya saliva, hingga usus halus ${ }^{18}$. Sedangkan aplikasi topikal, absorbsi berjalan begitu obatdilepaskan, lalu berpenetrasi kelapisan keratin, akhirnya ditangkap oleh kapiler darah ${ }^{20}$. Rute pemberian obat topikal berhenti sampai pembuluh darah lokal. Ini berkaitan dengan maksud aplikasi topikal yang memang hanya ditujukan untuk efek lokal ${ }^{21}$. MCT yang terkandung pada VCO dengan aplikasi topikal tidak dapat dikatalis oleh enzim lipase sehingga tidak dapat diubah menjadi monolaurin ${ }^{17}$.

Mengenai keadaan sistemik pasca pencabutan, tikus pada K1 dan K2 memiliki daya tahan yang tidak baik, karena agresivitasnya mengalami penurunan. Namun pada K3, Tikus memperlihatkan peningkatan aktivitas dan tampak lebih bugar dibanding kedua kelompok yang lain. Hal ini dipengaruhi oleh kemampuan VCO sebagai immunomodulator sehingga daya tahan tubuh tikus lebih baik².

\section{KESIMPULAN}

Kesimpulan dari penelitian yang telah dilaksanakan bahwa aplikasi VCO pada luka pasca pencabutan gigi menyebabkan terjadinya peningkatan jumlah sel fibroblas, Virgin Coconut Oil (VCO) mampu meningkatkan jumlah fibroblas 0,4 kali lebih banyak dari Povidon iodine, serta pemberian VCO dengan aplikasi per oral lebih efektif dan memberikan hasil yang signifikan terhadap jumlah sel fibroblas dibandingkan aplikasi topikal.

\section{DAFTAR PUSTAKA}

1. Ghosh P. K. 2006. Synopsis of Oral and Maxillofacial Surgery (An Update Overview). New Delhi :Jaypee, h. 6.

2. Sukartin J. K dan Sitanggang Maloedyn. 2005. Gempur Penyakit dengan VCO. Jakarta :Agromedia Pustaka, h : 7-12, 21

3. Peterson L. J. 2003. Contemporary Oral and Maxillofacial Surgery (4th ed.). St. Louis, Missouri : Mosby, h. 49-55.

4. Alam Syah A. 2006. Virgin Coconut Oil MinyakP enakluk Aneka Penyakit. Jakarta :Agro Media Pustaka, h. 1-2.

5. Susilowati. 2009. Pembuatan Virgin Coconut Oil dengan Metode Penggaraman. JurnalTeknik Kimia Edisi April 2009 Vol. 3. 2 : 246-51.

6. Wijaya A. I. dan Tasminatun Sri. 2012. Pengaruh Pemberian Berbagai Coconut Oil Secara Topikal terhadap Penyembuhan Luka Bakar Kimiawi pada Kulit Tikus Putih (Rattusnorvegicus) Terinduksi Asam Sulfat. Publikasi UMY FKIK (PendidikanDokter) Vol. 8. $9: 1-11$.

7. Nevin K. G danRajamohan T. 2010. Effect of Topical Application of Virgin Coconut Oil on Skin Components and Antioxidant Status during Dermal Wound Healing in Young Rats. Skin Pharmacology and Physiology. 23 : 29097.

8. Nuryanti A, dkk. 2008. Pengaruh Frekuensi Gelombang Ultrasonik (USG) terhadap Jumlah Sel Makrofag Luka Gingiva Kelinci. Jurnal 
Majalah Kedokteran Gigi UGM Edisi 15, h. 1-6.

9. Badman M. K dkk. Hepatic Fibroblast Growth Factor 21 is Regulated by PPARa is a Key Mediator of Hepatic Lipid Metabolism in Ketotic States. Cell Metabolism EdisiJuni 2007. 5 : 426-37.

10. Khoo T. Ldkk. 2011. A prospective, randomised, double-blinded trial tu study efficacy of topical tocotrienol in the prevention of hypertrophic scars. Journal of Plastic, Reconstructive and Aesthetic Surgery 2011. 64 : 137-145.

11. Prabakti, Y. 2005. Perbedaan Jumlah Fibroblas di Sekitar Luka Insisi pada Tikus yang diberi Infiltrasi Penghilang Nyeri Levobupivakaind dan yang Tidak Diberi Levobupivakain. Semarang :Univesitas Diponegoro Semarang, h. 17-23.

12. FroschleM dkk. 2004. Phytosteroid for Skin Care. Personal Skin Care 2004 :55-58.

13. Agero A. L danVerallo-Rowell V. M. 2004. A Randomized Double-blind Controlled Trial Comparing Extra Virgin Coconut Oil as a Mousturizer for Mild to Moderate Xerosis. Dermatitis Vol. 15. 3 : 109-16.

14. Lucida Henny, Salman, danHervian M. S. 2008. Uji Daya Peningkat Penetrasi Virgin Coconut Oil (VCO) dalam Basis Krim. Jurnal Sains dan Teknologi Farmasi Vol. 13. 1 : 1-8.

15. Joenoes Z. N. 2002. Ars Prescriben.Jilid 3. Surabaya :Airlangga University Press, h. 4753.

16. Dufour M dkk. 2007. Characterization of Monolaurin Resistance in Enterococcus faecalis. Applied and Environmental Microbiology Vol. 73 Edisi 2007. 17 : 55075515.

17. Widiyarti Galuh, Hanafi Muhammad, dan Soewarso W. P. 2009. Study on the Synthetis of Monolaurins Antibacterial Agents Againts Staphylococcus aureus. Indo. J. Chem. Edisi 2009 Vol. 9. 1 : 99-106.

18. Murray R. K. 2003. Biokimia Harper. Edisi 25. Jakarta: EGC, h. 664.

19. Katzung B. G. 2001. Farmakologi Dasar dan Klinik. Jakarta :Salemba Empat, h. 131-32.

20. Adams H. R. 2001. Veterinary Pharmacology and Therapeutics 8thedition. Oxford :Blackwell Publishing, h. 255

21. Arief Moh. 2007. Farmasetika. Yogyakarta :GadjahMada University Press, h. 39. 